\title{
Vandrere og hjemfarne
}

\section{Livsbaner og andre rumlige aspekter $\mathrm{i}$ The New York Trilogy og Blue in the Face}

N ew J ersey, Manhattan og Brooklyn er de amerikanske fixpunkter i Paul Austers foreløbige livsbane. E $n$ oplistning af forfatteren Paul A usters foretrukne settings er enslydende. Det er karakteristisk for Austers forfatterskab, at han gang på gang vender tilbage til selvbiografiens steder, endog til præcist angivne adresser hvor han har boet. Det skyldes, hvad angår det litterære oeuvre, ikke forfatterens behov for lokalkendskab, for man finder ikke detaljerede stedsbeskrivel ser hos A uster. Forklaringen ligger snarere i det forhold, at stednavnene og adresserne udgør pejlingspunkter for meditationer over selvet og identiteten. Ved at indlægge en selvbiografisk geografi i værkerne her tænker jeg især på trilogien, men også på M oon P al ace og L eviathan skabes et tekstrum, hvor forfatteren kan navigere mellem og forbinde selvbiografiske steder med sæaningernes baner. T ekstens miniunivers sæter på den måde forfatteren i stand til at iscenesætte betydningen af at opholde sig på steder, flytte sig og vende tilbage til samme sted.

J eg vil i denne artikel arbejde med dele af A usters forfatterskab på baggrund af en spatial betragtning og vise, hvorledes denne tilgang kan belyse såvel tematiske som formmæssige aspekter i værkerne. Det er især identitetstematikkernes mange spatiale udtryk, deres rumlige formgivning, der behandles. I forbindel se med The N ew Y ork T rilogy og specifikt den første del City of Glass sætter jeg fokus på gangens betydning, dens selvudforskende og værensforglemmende funktion og det betydningsfelt, der trakkes op mellem gåturenes baner i Manhattans grid, skriften og læsningens bevægelse. I romanens optegning af gangens ruter på kortlignende blade bliver skridtene i gaderne direkte omsat til ord og betydning. Auster anvender i forbindelse med psykologiske og erindringsrelaterede tematikker et motivsæ, som også kan analyseres på grundlag af en rumlig betragtning. D et gælder blandt andet væ relset og æskens markante funktioner i trilogien og i »The Book of Memory « fra The Invention of Solitude. A fslutningsvis behandles selve rumrepræsentationen i værkerne, og det er her jeg vil inddrage A usters filmarbejde. Et perspektiv på A usters værk, der inkluderer filmene, synes at kondensere en aktuel rumlig problematik, nemlig orienteringsvanskelighederne i opbrudte, 
heterogene og netværksorganiserede rumligheder og en eftersøgning af sted, dvs. en fordybelse i og en forståelse af sammenhæenge mellem det subjektive og subjektets sted, mellem stedet og identiteten. I filmene f.eks. i form af forsøget på at skildre et steds atmosfære, en genius loci. ${ }^{1}$

\section{Fodgænger i City of Glass. At gå det indre ud}

»N ew $\mathrm{Y}$ ork was an inexhaustible space, a labyrinth of endless steps, and no matter how far he walked, no matter how well he came to know its neighbourhoods and streets, it always left him with the feeling of being lost. Lost, not only in the city, but within himself as well... and this, more than anything else, brought him a measure of peace... On his best walks, he was able to feel that he was nowhere. And this, finally, was all he ever asked of things: to be nowhere. N ew $\mathrm{Y}$ ork was the nowhere he had built around himself, and he realized that he had no intention of ever leaving it again. $\ll^{2}$

Centralt i romanens indledende beskrivel se af karakteren Quinn står behovet for at vandre uden mål i Manhattans gader. Quinn går med den hensigt at forvilde sig og ved hjælp af sanseindtrykkene at skylle sig selv ud af sig selv. D en orienteringsløse gang og selvfortabelsen bliver således selve målet for vandringen. Gangen producerer et intetsted, som gennemrejses af Quinn samtidig med, at det produceres i gangen. ' taught him to understand the connectedness of inner and outer. U sing aimless motion as a technique of reversal, on his best days he could bring the outside in and thus usurp the sovereignty of inwardness, «hedder det senere i romanen (NY T, p.61). Det perspektiv på gangen fremstiller karakteren Quinn som en art Möbius-bånd, hvor det ydre forvandles til noget indre og omvendt. D ermed udlægges også en læsestrategi for romanen som helhed. H vad Quinn oplever i N ew Y ork foregår på en scene, hvor ydre begivenheder på én og samme tid skal opfattes som begivenheder og som tanker og bevægelser $\mathrm{i}$ sindet. R omanens N ew Y ork er konkret Manhattans gridsystem, Broadway og W ashington Square, men også sindets dunkle eller netop hos A uster snarere sindets glimtende, illusionsflimrende spejl- og glasreflekterede topografi. Men det er ikke et spørgsmål om, at eksterioritet spejler interioritet, som fiktionens landskaber kan symbolisere følelser, eller at den vertikale akse i huset fra kvist til kælder spejler psykens topik i en 1:1-logik. Hos Auster er det mentale og det fysiske gensidigt indlejret i hinanden, og karakteren er et relæ for skiftene mellem det ydre og det indre. En grundlæggende karakteristik af 
$\mathrm{N}$ ew $\mathrm{Y}$ ork T rilogiens æestetiske projekt er den konstante omvending mellem det indre og det ydre i de tre romaners undersøgelser af selvet og identiteten. I gangen internaliseres det ydre, mens det indre eksternaliseres og projiceres ud på en flade, som efterfølgende gennemvæves af karakterens skridt. R omanens første formuleringer om Quinns gåture fokuserer på gangen som et middel til et befriende identitetstab, men set i relation til romanens omvendinger mellem det ydre og det indre er gangen samtidig at forstå som en bevægelse ind på selvets eksteriøre flade og dermed er gangen en selvudforskning.

\section{Gangens intetsted}

Det »nowhere« som A usters karakter producerer og forbruger i gangen, vil jeg relatere til Michel de Certeaus opfattelse af gangen i L'invention du Q uotidien. Her er gangen anskuet som en praksisform, hvor bevæegelsen mod det andet uafladeligt skaber fravær. ‘A t gå er at mangle et sted. Det er den ubestemte proces, hvor man er fraværende og søger det egentlige sted [un propre]. Bevægelserne frem og tilbage, som byen multiplicerer og koncentrerer, gør byen til en grænseløs, social erfaring af at mangle et sted. « de Certeau fortsæter beskrivelsen med at understrege, hvorledes fodgængernes baner også mødes og krydses og derved danner et sted, danner den urbane tekstur, men byen som sted forbliver uden identitet, byen er kun et navn, set mylder af forbipasserende«s vet univers ... der hjemsøges af et intetsted eller af de drømte steder «(I Q, p. 155). Med udgangspunkt i F reuds fort-da-analyse i Der T raumdeutung og $\mathrm{J}$ enseits des $L$ ustprinzi ps beskriver de Certeau relationen til rummet og konstitutionen af sted og eksterioritet som en funktion af barnets differentiering fra moderens krop. At gå forstås som en gentagel se af de infantile oplevelser af andethed og fravær. »A t praktisere rummet er altså at gentage barndommens glade og stille oplevelser; det er på et sted at være anden og bevæge sig mod den anden, [être autre et passer à l'autre] «I Q, p.164). Man kan i gangen få sig selv til at gå væk og komme igen. Quinns gang i byens gader er således det motiviske udtryk for romanens udforskning af selvet. Gangen som praksisform bringer subjektet til fysisk at gentage de fundamentale processer, som er dets forudsætning og grundlag, dvs. i skridtene gentages til stadighed identitetens grundlag i adskillelsen fra moderen, i adskillelsen fra andre og relationen til andre.

Quinn bruger sin tid på at sk rive og læse kriminal romaner eller på at gå. Allerede ved denne sammenstilling af aktiviteter peges der på sammenhæenge mellem gang, skrift og læsning. Det intetsted, Quinn producerer under sine 
gåture svarer til det rum, der produceres under læsningen, hvor jeget også vandrer $i$ et »nowhere« »At læse er at være et andet sted... i en anden verden; det er at konstituere en hemmelig scene, et sted som man kan træde ind i og forlade når man ønsker det... Læseren producerer haver, som gør en miniature ud af og sammensæter en verden, ligesom en R obinson Crusoe opdager en $\varnothing$ «(I Q, p.250). At skrive beskriver Michel de Certeau som en praksis, hvor man initierer en verden på papirets blanke side ved at gå på siden med pennen. Gangen, læsningen og skrivningen er således ensdannede praktikker, for så vidt som de skaber egne al ternative eller utopiske verdener. Dermed får A usters tematiske fokusering på skrivningen som praksis og fiktionen som produkt også sit spatiale udtryk i gangen.

\section{Gangens skrift}

V ed et tilfældigt, fejlplaceret tel efonopkald forvandles Quinn til detektiv og får til opgave at skygge Mr Stillman senior. Stillman synes at være tvangsgænger. H an går uafbrudt fra morgen til aften i N ew Y orks gader, og Quinn følger efter, mens han noterer Stillmans bevægelser i sin røde notesbog. Hidtil har gangen og skriften været to adskilte aktiviteter for Quinn; nu bliver gangen og skriften uadskillelige dele af samme bevægelse. Skriveprocessen er rykket ud på gaderne, og skriftens bevægelse hen over papirsiden er blevet sammenfaldende med kroppens bevægelser hen ad gaden. Man kan næppe forestille sig en mere konkret dramatisering af skriften og fortællingens spatiale karakter, bevægelsen frem. Fortælingen går. Og dog, for det viser sig, at Stillmans gåture for hver dag danner et bogstav, der kan læses. Gangen er simpelthen skrift, kroppen et skriveredskab og Manhattans gridsystem det hvide papir. Skriften træder frem som et kropsligt begær, overvædende i en grad så hele kroppen må skrive, sådan som Quinns rystende krop skriver rystende, ofte ulæeselige bogstaver i notesbogen. Samtidig er det netop en 'levende skrift', som må ligne livet, fordi den følger livets bevægelser, og derfor også et eksempel på det mimetiske sprog, som romanen kredser om med inddragelsen af Babelsmyten og diverse mimetiske, mysticistiske sprogopfattelser. Quinn går med notesbogen støttende på venstre hofte, smuch as an artist holds his pal ette og kan nu både se op på Stillman foran og ned på skriften $\mathrm{i}$ bogen, sseeing the thing and writing about it in the same fluid gesture« (N Y T , p.63). Skriften er i gangen forfattet helt tæ på det objekt, den skal repræsentere; der er flydende overgang mellem repræsentation og repræsenteret. Skrevet gående bliver skriften altså flydende og mimetisk, en sprogopfattelse som samtidig effektivt undermineres af samme passages metafo- 
rik. Valget af malerpaletten og dermed et ikonisk repræsentationssystem kommer her til at fungere som skriftens støttehjul.

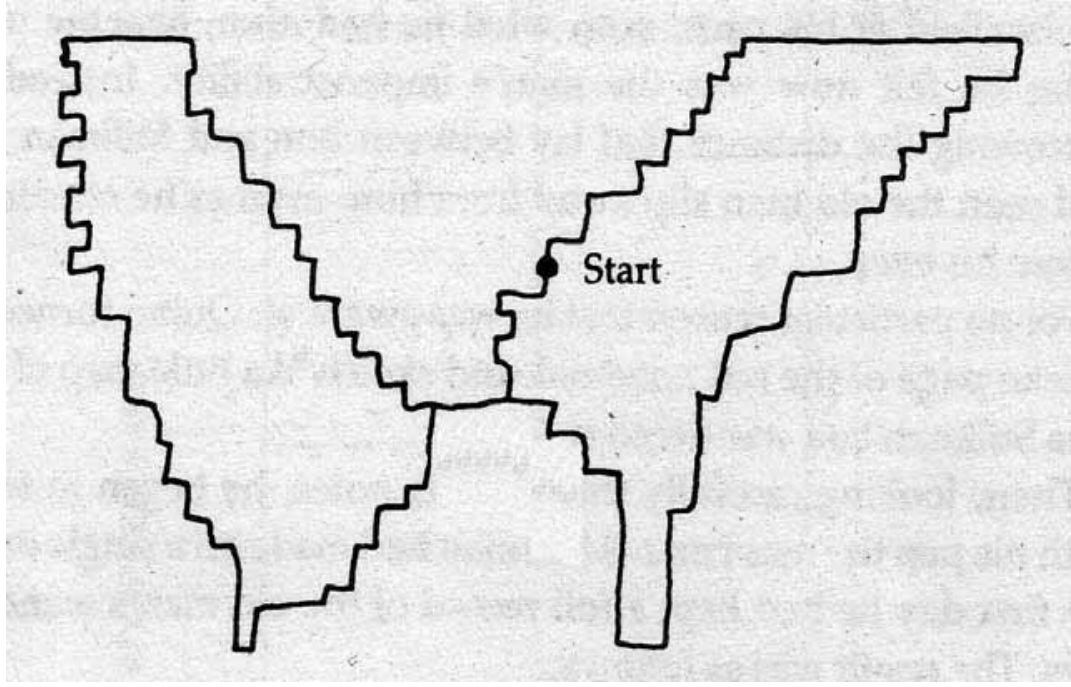

Bogstaverne, Stillman skriver med gangen, som Quinn gentager med sine skridt og med pennen på papiret, som om det var en diktatøvelse, danner ordene »The T ower of $\mathrm{B}$ abel « Vi får senere bel æg for at opfatte gåturens bane som en metafor for den biografiske livsbane. Og i Stillmans tilfælde former livsbanen sig altså umiddel bart til fuldt læselige bogstaver og ord. Måske. Quinn skrev ikke ned de første dage og de to sidste bogstaver mangler. 'Quinn paused for a moment to ponder what he was doing. W as he scribbling nonsense? (NY T, p.68). Det kan være tilfæd dige krusseduller eller bogstaver med skæbnetung betydning. T vivlen gælder også muligheden for at se et mønster i livsfortællingen og biografien. Spørgsmålet om det legitime i fortolkningen, i at se bogstaver i Stillmans gang, gentages siden i forbindelse med Quinns egenhæendige gåtur og nu på en måde så læseren involveres direkte i overvejelserne omkring konstruktion af betydning.

'H e walked down Broadway to 72nd Street, turned east to Central P ark W est, and followed it to 59th Street and the statue of Columbus. There he turned east once again, moving along Central Park South until Madison A venue, and then cut right, walking downtown to Grand Central Station...«(NY T, p.106). 
Gåturen fortsæter hen over to tryksider fyldt med gadenavne. T urbeskrivelsen er stort set blottet for iagttagel ser; først efterfølgende gør A usters Quinn sig notater om de eksistenser, han har set undervejs. Turen går fra upperwest-side til Manhattans sydspids og op igen til FN -bygningen. Læst på baggrund af de forudgående kortillustrationer i romanen og Quinns tydningsforsøg, fungerer den minutiøse turbeskrivel se som en opfordring til læseren om på samme måde at kortlægge ruten, læse tegnene og derved løse gåden. U den besvær kan læseren tegne og føl ge Quinn i Midtowns grid, af og til taber man ham af sigte i 'the financial district' og på Lower East Side, men på vej op ad Bowery kommer han til syne igen. Men ruten har ikke form som et genkendeligt bogstav eller tegn. ${ }^{4}$ I gennem pennens ofte tøvende bevægelse i optegningen af ruten og i forsøgene på at etablere mening i resultatet oplever Iæseren helt konkret, mærker på egen pen, den tvivl og forvirring omkring tegnene, som romanen tematisk fremskriver med anvendelsen af Babelsmytestoffet og de mimetiske sprogteorier. ${ }^{5}$

I Stillmans kort mangler de to sidste bogstaver i ordet Babel; derved lader A uster muligheden for 'babble' (pludren, tom snak) stå åben for Iæserens overvejelse. K ortet over Quinns vandring former ikke genkendelige bogstaver og skriver dermed også pludren. På den måde har læseren været involveret i at give nonsens et konkret udtryk i romanen. Men den læseraktiverende demonstration af afkodningernes potentielle efter-og fejlkonstruktioner er kun et af stroppeturens betydningsaspekter. Den fungerer også som en komprimeret version af et helt livs gåture og er dermed del af romanens udforskning af selvet og ikke mindst dens overvejelser over mulighederne for at forstå og beskrive selvet. H e wondered what the map would look like of all the steps he had taken in his life and what word it would spell«(NY T, p.129). Som i tegningen af storken hos $\mathrm{K}$ aren Blixen i D en A fri kanske $\mathrm{F}$ arm tænkes livets umiddelbart meningsløse skridt her at optegne en skæbne eller mere generelt at forme et ord, der rummer fortolkningsnøglen til det enkelte liv. Men manglen på resultater af det detektivarbejde Quinn sendes ud på og gåturens nonsens dementerer selvsagt en essential istisk forestilling om, at individets livsbane rummer en sandhed, en art konklusion der lader livet gennemlyse og aflæse. Livsbanen lader sig ikke læse. Der findes ikke et punkt, hvorfra et overblik kan samle skridtene i et meningsfuldt tegn. Det forskyder sig i City of Glass på samme måde som gangen ifølge de Certeau hel e tiden mister sit sted. Mulighederne for at belyse skriften med gangen og omvendt udnyttes således virtuost i City of Glass: fra opfattelsen af gåturenes baner i byens grid som livsbaner, som læselige livsfortolkninger eller fuldstændig ulæsel ige manifestationer, til parallellerne mellem gangens produktion af et ikke-sted som på én gang udtrykker identitetens betingelser og ikke-stedet der produceres 
i læsningen, til sammenligninger hvor fælleselementet er udforskningen af selvet.

Til slut i romanen opholder Quinn sig i et lille værelse i familien Stillmans Iejlighed, hvor han i en neddrosling af alle andre aktiviteter, en art kunstlo-

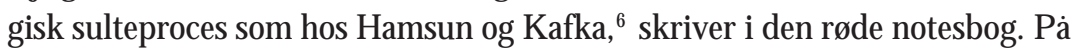
det uundgåelige tidspunkt, hvor bogens sider er fyldt med skrift og Quinn må standse pennen, ophører karakteren Quinn med at eksistere. $H$ an er forsvundet fra værelset, forsvundet fra romanens skrift. K arakteren og dermed også selvet er således set som et fiktivt konstrukt båret af sproget. Men det betyder omvendt også, at selvet virkeliggør sig gennem sproget. Skriften og dens andet udtryk, gangen, er i City of Glass de redskaber, subjektet har til selvudforskning og selvrealisering. Skriften eftersøger selvet ned over den linierede side på samme måde som Quinn i gangen er på jagt efter sig selv i Manhattans grid. Men den efterstræbte tilstand af selvidentitet lader sig ikke indhente. Quinn citerer i 'the red notebook' fra Baudelaires prosadigt 'A nywhere out of the world «i Les Spl een de P aris: 》્y I me semble que je serais toujours bien là où je ne suis pas. I n other words: it seems to me that I will al ways be happy in the place where I am not «(NY T, p.110). Også således forstået er gangens fraværsproduktion jegets eksistentielle vilkår. H os A uster er gangen dermed også udtryk for en længsel hos jeget, en hjemløshed og en permanent tilstand af selvfravær, af at være 'ude af sig selv'.

\section{Selvets papæske}

Stillman senior traver foran Daniel Quinn. B egge noterer de samtidigt i røde notesbøger, Stillman nedskriver selvopfundne mimetiske navne på de ting, han finder efterladt i gaderne, Quinn skriver om Stillmans fund og bevægelser. Stillman fungerer altså som et spejlbillede af Quinn. H an påtager sig samtidig sin egen fiktive karakters identitet, W illiam W ilson, et navn lånt fra en af Edgar Allan P oes fortællinger. Senere optræder han som H enry D ark, der viser sig at være en fiktiv person, og han har fælles initialer med D on Quixote, illusionsridtets mester. Quinns person er således tømt for identitet, han er fordoblet, spejlet, forvrænget og splintret i en mængde brudstykker, som er projiceret ud i rummet i form af andre fiktive karakterer. Det er karakteristisk for A usters forfatterskab, at identitetsspørgsmål og andet psykologisk konfliktmateriale på denne vis spatialiseres. Romanerne Ghosts og The L ocked R oom - de øvrige to dele af T he N ew Y ork T rilogy - arbejder med samme æstetiske plan og form. 
I G hosts overvåger personen Blue en mand ved navn Black i lejligheden overfor. Blue viser sig at være Blacks fiktive konstruktion. Blue ('out of the blue') er en springgnist af Blacks bevidsthed, der til slut slår sin forfatter ned, stjæler manuskriptet og forhåbentlig rejser til K ina, ifølge en jegfortæler. A Itså et setup der lader fiktive fiktive personer krydse klinger med kun fiktive personer. Da Blue i forklædning første gang snyder sig ind i Blacks lejlighed, folder identiteterne sig ind i og ud af hinanden på dørtrinnet: »He knocks, the door opens, and suddenly there is no more distance, the thing and the thought of the thing are one and the same. Then it's Black who is there, standing in the doorway with an uncapped fountain pen in his right hand...«(NY T, p.184). G hosts handler om skriveprocessens materialisering af det indre i det ydre, om forfatterens tanker der forvandler sig til ting og personer, om forfatteren der ikke er sout of [his] mind, «men stoo much in [his] mind (NY T , p.193) og om urban anonymitet og isolation. I G hosts anvender Auster en minimalistisk æstetik og en næsten geometrisk formaliserbar rokering af bevidstheders positioner i et yderst afgrænset rum. $\mathrm{E}$ / to bevidsthed(er), en/ to lejlighed(er). De materialiserede bevidstheder veksler mellem at være delvis overlappende, adskilte eller helt sammenfal dende. De befinder sig i et byrum, hvor lyden fra en bil på Brooklyn Bridge og gadenavnet Orange Street i Brooklyn H eights er de sparsomme realistiske fixpunkter i en rumkonstruktion, der ellers er abstrakt og rungende tom. Som i City of Glass, men dog endnu mere udtalt her i G hosts, lader Auster det hvide papir skinne igennem skriftens version af et $\mathrm{N}$ ew $\mathrm{Y}$ ork. Tomhederne i den spinkle rumkonstruktion virker som illusionsbrud, og man kan næsten høre fiktionens maskineri arbejde f.eks. i mødet mellem Black og Blue. Samtidig resonerer rummets uvirkelige tomhed omkring karaktererne det tematiske fokus på illusioner i identiteten, dens indhold af konstrukter og uvirkelighed.

I The Locked R oom, der handler om en jegfortællers relation til barndomsvennen Fanshawe, finder A uster på samme måde spatiale udtryk for det mentale, fra barnet $F$ anshawes private papæske og hans ophold i en åben grav som teenager, til kufferten med F anshawes saml ede papirer, til det aflåste væ relse, der er Fanshawes sidste tilholdssted. Her er alle æskerne og de lukkede rum metaforer for jegets afsondrethed: $\gg . .$. we become more and more opaque to ourselves, more and more aware of our own incoherence. No one can cross the boundary into another - for the simple reason that no one can gain access to himself«(NY T, p.247). J egpersonen kan jagte Fanshawe og sig selv til verdens ende uden resultat. IE skemetaforikken fremstiller således jeget som uigennemskueligt for sig selv og forståelsen af den anden, fremmedpsyken, som umulig. Romantitlens reference til kriminal romanens undergenre 'det 
aflåste værelse', hvor liget bliver fundet i et vær else låst ind efra, sammenfatter denne rummetaforik. E E skens snævre rum anvendes al tså som udtryk for en tilstand af isolation og lammelse, men den kærlige og erotiske forbindelse med omverden udtrykkes også som tilstande i rum hos Auster.

M ore often than not, we wound up making love... the house was slowly eroticized, transformed into a domain of sexual possibilities. The nether world rose up to the surface. E ach room acquired its own memory... a particular patch of carpet, say, or the threshold of a particular door, was no longer strictly a thing but a sensation, an echo of our erotic life« (NY T, p. 243).

Her træder jeget i et dialogisk forhold til det omgivende rum og dets genstande, der emmer af personlig historie skabt i samværet med en anden. På harmonisk vis er seksualitetens "nedre«steget op og indlej ret i overfladens synlighed. Altså en markant kontrast til de mange trange, nøgne, lukkede rum og skakter i trilogien. I »T he Book of Memory «i The Invention of Solitude gør Auster sig overvejelser over værelsets litterære og eksistentielle problematik: »T o withdraw into a room does not mean that one has been blinded... « og sthe room need not be an image of hermetic consciousness... « A uster søger her at nuancere værelsets betydninger; det er udtryk for andet end blot isolation. I »T he Book of Memory«og i trilogien er ophold i værelset en metafor for arbejdet med at sk rive og for arbejdet med selverkendelse og forståelse af identiteten. F orbindelsen til omverdenen er ikke nødvendigvis afskåret i værelset, den er blot udfoldet gennem tanken; værelset kan have vinduer, pointerer A uster (IS, p.140ff). D e snævre rum er ikke betragtet som det åbne rums modsætning, men som jegets nødvendige sluse ind i forestillingernes åbne rum. I kke ulig P rousts skildring af den unge Marcel, der foretrækker de dæmpede lyde af sommer, der når ind i værelsets mørke frem for en gåtur ude i sommeren, fremhæever Auster den intensiverede forestillingsaktivitet om det fraværende, som værel set tillader. ${ }^{8}$ । ovenstående passage fra trilogien virker den Proust-inspirerede erindringsfil osofi tillige; rummet flyder over, ikke af liv, men netop af erindring om liv.

I trilogiens sidste roman kædes en opfattel se af jegets aflåste indre samtidig sammen med biografien og autobiografiens problem, dvs. med vanskelighederne i at fortælle jeget. J eget undslipper skriftens indkredsningsforsøg og forskyder sig igennem og til sidst ud af alle tre romaner. I trilogiens afslutning nægter $F$ anshawe at forlade sit værelse, og jegpersonen overlades en rød notesbog, hvor ordene aflyser og ophæver hinanden og synes at være »too willed, something too perfect«(NY T, p.314). Selvbiografiens selvforklaringer 
rives itu side for side, og jegets forsøg på at nå sit eget jeg gennem et andet opgives. ${ }^{9}$

H os A uster er der en tematisk fokusering på subjektets fragmentering og en anti-essentialistisk opfattelse af dets konstruktion og uigennemsigtighed. De mange personfordoblinger, tomme identiteter og fiktive fiktive karakterer er blevet læst, ofte med dekonstruktionen som grundlag, som udtryk for postmoderne centrumsløshed og subjektets decentrering. D et gæader Alison R ussell, Steve E. Alford, Bo K ampman W alter og Bernd H erzogenrath, jf note 1 ovenfor. J eg finder det væsentligt at fremhæve trilogiens paradoksale modsigelsesfuldhed på netop dette punkt. For hver gang identiteten ophæeves og dementeres med legende, metafiktive håndbevæegelser, så hæavdes den med fuld styrke i en eftersøgning af samme. Og ser man på, hvorledes A uster opbygger sine karakterer og deres interaktion og ikke mindst på metaforiseringen af identiteten og subjektet, er en essentialistisk opfattelse af jeget og forbindelsen bagud i traditionen tydelig. Den spatiale litterarisering af subjektet og psyken har forbindelse til det romantiske gys med dobbeltgængermotivet hos f.eks. H.C. A ndersen og E.T.A. H offmann. A usters referencer til Edgar Allan Poe er heller ikke blot en intertekstuel reference til detektivgenrens ophavsmand og til en af fædrene i amerikansk litteraturhistorie. Mere specifikt er der et slægtskab i den litterære omgang med subjektet. Poes præsymbolistiske fortæl linger arbejder på samme måde som Austers med en spatial isering af det mentale, f.eks. i »T he Black Cat« hvor psyken udstilles som nedbrændt hustomt for naboernes og læeserens blikke eller i dobbeltgængerfortællingen »W illiam W ilson«, som A uster henviser til med navnelånet. Men uregerligheden i P oes prosa, hvor subjektets ukontrollerbare psyke spejles i sætninger, hvis syntaks og semantik ikke formår at binde enkelte ord i kontekster, adskiller sig væesentligt fra Austers prosa i N ew $\mathrm{Y}$ ork T rilogien. Den er distanceret, nøgtern, gennemsigtig, realistisk grænsende til det minimale, og den opløsning af subjektet, som A uster får frem, beror ikke på sproglige eksperimenter, men netop på udnyttel sen af særdel es konkrete metaforiseringer af identiteten og mentale processer, som så i deres bogstavelighed kan eksplodere op i læserens ansigt.

$V$ ærelset er som nævnt et centralt motiv $i$ The Invention of Solitude, The $\mathrm{N}$ ew $\mathrm{Y}$ ork T rilogy og M oon Palace. J egets identitetsudredning, dets ensomme arbejde med at skrive, dets fantasiaktivitet såvel som erindring er metaforiseret ved hjælp af værelsets billedlige muligheder. Gaston Bachelard har i La poéti que de l'espace analyseret huset som topografi for vores intime væ ren og som et af fantasiens væsentligste billedlige redskaber til analyse af menneskets følelsesliv. ${ }^{10} \mathrm{~V}$ ærelset har tydeligvis en sådan prioritet i Austers tidlige forfatterskab. Her vil jeg dog ikke lægge mig i forlængelse af Bache- 
lards såkal dte topoanalyse og dens reference til begrebet om den 'rene fantasi', der er uafhæengig af perception, kultur og historie. I det følgende vil jeg netop betragte A usters byrepræsentationer i deres historicitet, såvel trilogien som filmene.

\section{Prosaens New York}

Rumrepræsentationen i City of Glass er, som det vil fremgå, særdeles sammensat og modsigelsesfuld. Quinns omtalte gåture på Manhattan er en topografisk vandring i USA s historie, der (dog uden historisk kronologi) går fra opdagelsen af det nye land med Columbus-statuen på Columbus Circle, til oplæsningen af uafhængighedserklæringen på Bowling Green til borgerkrigen med General Grant Memorial i Riverside Park og til mindesmærket W ashington Memorial Arch for USAs første præsident i Washington Square Park. ${ }^{11}$ Som symbolske fikspunkter i romanens setting fortæler mindesmærkerne historien om A merika som politisk og social utopi, en historie der samtidig spejles i plottets metafysiske ideer om genrejsningen af Babelstårnet i Boston og den kommende paradisiske tilstand, hvor alle i A merika igen vil tale guds sprog. Men indlejret i den kollektive histories setting ligger samtidig reminiscenser af forfatterens personlige historie. $\mathrm{N}$ ew $\mathrm{Y}$ ork er Auster-land, ligesom Baltimore i T imbuktu kaldes » oe-land « A uster skriver sin egen historie ind $i$ byen ved at anvende selvbiografiske adresser, f.eks. West 107th Street hvor han boede i begyndelsen af 70erne og V arick Street nummer 6 hvor han boede i en periode omkring 1979. ${ }^{12}$ I The Invention of Solitude er adressen i V arick Street også det konkrete udgangspunkt for de omtalte overvejelser omkring erindring og værel sets motiviske betydninger, og adressen W est 107th Street forekommer igen i Leviathan. Andre stedsangivelser, f.eks. morfarens lejlighed på Central Park South og Columbus Circle, optræder også flere gange i forfatterskabet. D en æstetiske leg med blændværker i identiteten og spillet med forfatteridentiteten fungerer altså i settings, som placerer subjektet i en national og biografisk historicitet; den nationale i form af landets historie og dets oprindelse i utopien; den biografiske i form af en repetitiv afsøgning af selvbiografiens steder.

A uster leger med et biografisk material es tilstedeværelse i forfatterskabet, f.eks. i trilogien når han opløser forskellene mellem en karakter og forfatternavnet ved at lade den fiktive forfatter bære navnet $P$ aul Auster. D e selvbiografiske adresser vidner om, at værkerne også på dette plan er en meditation over selvet og identiteten. A dresserne er signal poster i teksterne, som viser hen til erindringen, til betydningen af at flytte sig og vende erindrende og 
skrivende tilbage til sine steder..$^{13}$ Deres tilstedeværel se i teksterne kan belyses med de Certeaus forestilling om skriften som en spatial praksis. Skriften er sen serie af artikulerede operationer (gestiske eller mentale)... spor på siden, bevægelsesbaner som tegner ord, sætninger og til sidst et system. «Skriften er her opfattet som en vandring hen over det hvide papir, der former set artefakt, en anden 'verden'« (I Q, p.134-35). H vad vi ser hos A uster er, at skriften som spatial praksis forbinder selvbiografiens og fortidens steder. Skriften går over jegets land igen. Men læseren vil selvfølgelig, også efter at have konsulteret Austers autobiografier, forblive uvidende om stedernes betydningsmæssige indhold. "Steder er fragmenterede og indadvendte historier, fortider som andre ikke får lov at læse, akkumuleret tid «(I Q, p. 108). I den selvbiografiske geografi udlægges sporene til en erindringsbaseret selvforståelse, således som den er beskrevet i The Invention of Solitude, men geografien lader sig ikke aflæse for erindringsindhold. ${ }^{14}$

Byfremstillingen i City of Glass tilsigter gang på gang at fremhæve repræ sentationens karakter af repræsentation. D et N ew Y ork, der er forsynet med historie gennem mindesmærker og topografisk svarer til virkelighedens Manhattan, er samtidig tomt og livløst, en todimensional flade, der bruges til indskrifter, stille i en grad der peger på, at vi ikke er i østkystens metropol, men inden i Quinns bevidsthed. Få og ganske korte beskrivelser af vej ret eller baseball på tv i en diner formår ikke at brydefornemmelsen af, at vi følger marionetter i en kulisse af Manhattan. Inden i den magre byrepræsentation indlejres en anderledes kødfuld og komprimeret beskrivelse af byens liv i form af Quinns notater fra den lange gåtur. T ekststykker om bumser, posedamer, alkoholikere, gale: »H ulks of despair, clothed in rags, their faces bruised and bleeding, they shuffle through the streets as though in chains. Asleep in doorways, staggering insanely through traffic, collapsing on sidewalks..." (NY T, p.109). To siders detail registererende, modernistisk montageprosa, der har både indholds- og formmæssige fællestræk med Baudelaire og Rilkes beskrivelser af $\mathrm{P}$ aris, skyder sig her ind i den metafiktive byrepræsentation. Beskrivelsen af byens sociale virkelighed, byen som »this particular hell«(ibid.) nærmest eksploderer med lydene af en klarinet og de gales remselignende forbandelser i den ellers absurd rigoristiske og hyperreferentielle opregning af gadenavne i Quinns tur. "Some will starve to death, others will die of exposure, still others will be beaten or burned or tortured « (N Y T, p. 109). Optegnelserne om de fortabtes $\mathrm{N}$ ew $\mathrm{Y}$ ork gør det samtidig tydeligt, at Babelsmytestoffet og turen i A merikas historie ikke alene tjener den simulatoriske leg med tegn og faldene igennem fiktionslag, men henviser til de nationale utopiers mangelfulde realisering. Austers $\mathrm{N}$ ew $\mathrm{Y}$ ork er en skrammelstak af alskens nedbrudthed: »T he broken people, the broken things, the broken 
thoughts. The whole city is a junk heap (NY T, p.78). R omanens brug af Babelsmyten udtrykker håbet om forløsning for byen. Endelig mimer montageformen i Quinns skrift i notesbogen en fragmentering i sansningen, og passagen er således en af to passager i City of Glass, hvorom man kan sige, at byen $\mathrm{N}$ ew $\mathrm{Y}$ ork og mere præcist betingelserne for sansning, som metropolen giver, sæter sig igennem i romanens stilistiske udtryk. Men tekststykket sluttes som næevnt med et citat fra et af B audelaires prosadigte om Paris, hvad der igen flytter fokus, således at Quinns montage snarere forholder sig til en anden tekst og dermed faktisk sender Iæseren tilbage til en historisk bysansning, som vi kender den beskrevet hos W alter Benjamin eller Georg Simmel.

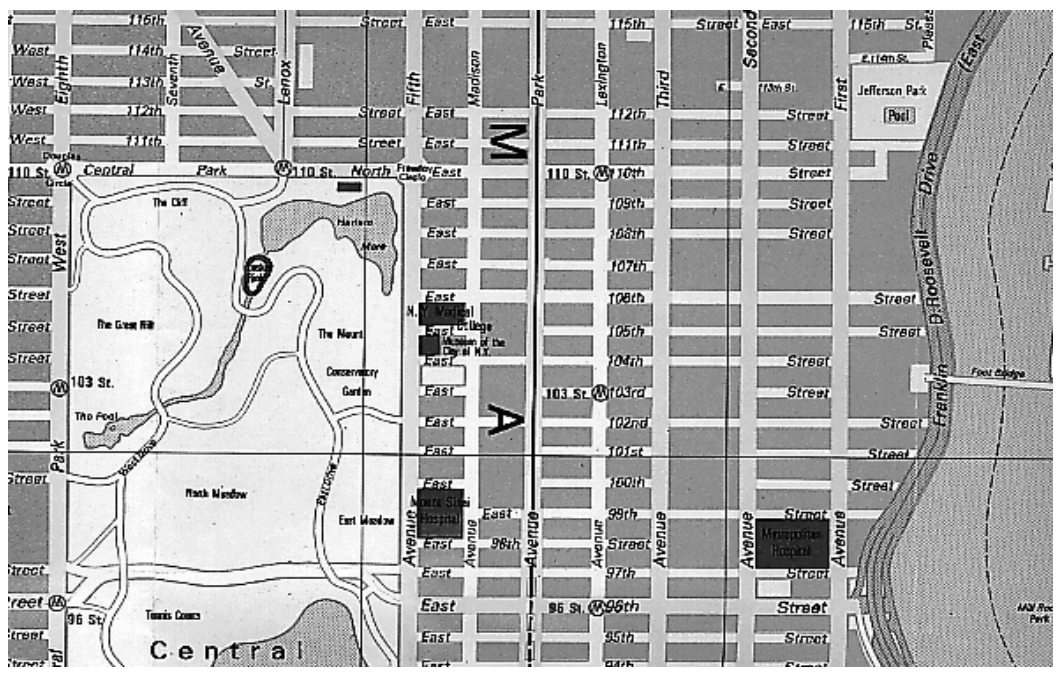

City of Glass indeholder sål edes modstridende repræsentationer af byen $\mathrm{N}$ ew Y ork. En dominerende der producerer et uvirkeligt, metafiktivt ordsted. Det sker i de forskellige metaforiske konstruktioner, hvor Manhattan anskues som et stykke papir, som R obinson Crusoes øde ø og som en tekst hvor en person kan blive til et punktum. Eller som tidligere bemærket en Iæsningens have, et ikke-sted. Hertil føjes andre beskrivelser, der er realistiske, enten ved at benytte byens konkrete og historiske topografi som setting eller realistisk i den forstand, som montagen formmæssigt forholder sig mimetisk til perceptionen. A uster tilføjer endelig et systemisk perspektiv på byen ved at inddrage telefonnettet i intrigen. ${ }^{15}$ De tel efonopkald, der løber vild i systemet og det telefonnummer, der altid er optaget, repræsenterer en objektiveret, anonymiseret og paranoiafremmende sansning af den urbane netværksstruktur. Romanen eksperimenterer således med at lade forskellige rumkonceptioner 
folde sig ind $\mathrm{i}$ hinanden. Resultatet er en roman med en heterogen rumrepræ sentation, hvor læseren oplever bratte skift. Det er tilfældet i skiftet mellem den verbale beskrivelse af Stillmans rute og indtegningen af ruterne på kortene. P assagen med beskrivelsen af Quinns lange gåtur bryder den realistiske repræsentation, fordi det narrative forløb mister sin fylde, når det klemmes af den voluminøse opremsning af gadenavne. R esultatet er hyperreferentialitet og dermed nedbrud i den real istiske diskurs. K ortgengivelserne er geometriske, til dels ikoniske repræsentationer af rum, der oftest optræder i rejselitteratur, men også i detektivgenren, f.eks. hos A rthur Conan D oyle i Sherlock Holmes-fortæll lingerne, hvor kortskitsen er et redskab i opklaringen og på samme måde som A usters kort har en læeseraktiverende funktion. De middelalderlige tegnforestillinger om homologi mellem himmel og jord og om objekternes Iæselighed, som Stillman filosoferer over, omhandler indholdsmæssigt en historisk repræsentationslogik baseret på lighed (jf. Foucaults Les $M$ ots et les choses), men i det øjeblik hvor læseren bliver kodeknækker, f.eks. som i mit forsøg på at læse Quinns tur efter de samme regler som Stillmans læses i romanen, i det øjeblik har læseren omfortolket det blot indholdsmæssige til regler for hvordan skriften skal læses, dvs. som bevægel ser på et kort. Andre passager mimer som næunt modernistiske byrepræsentationer og i andre igen råder en psykologisk repræsentationslogik, hvor det psykiske er projiceret ud som illusioner og fiktioner. Det gælder de steder, hvor teksten indikerer, at begivenhederne er Quinns fantasterier, f.eks. i passagen hvor Stillman beskrives som usynlig (N Y T , p. 15). R omanen er således heterogen, hvad angår repræsentationslogik og rumrepræsentation eller - med et andet begreb som jeg skal vende tilbage til - den former et litterært hyperspace.

D en heterogene rumrepræsentation, Manhattan som en opbrudt, sammenstykket illusionsflimrende glasby indrammer og spejler subjektivitetens splintring, men ikke således at der i romanen trakkes egentlige forklaringslinier fra sociol ogiske, urbane omstændigheder til subjektets identitetseftersøgning. En sådan sammenhæang finder man andetsteds, i A usters roman In the Country of Last Things, som er skrevet samtidig med trilogien og udkom 1987. Her ekspliciteres sammenhængen i en mareridtsagtig, kulturkritisk version af det sociale sammenbrud i storbyen. Romanen foregår i en lovløs by af skrammelsamlere og selvmordere, præget af vold, bondefangeri og ekstrem fattigdom. I mareridtsvisionen spiddes karakteristiske situationer fra det moderne byliv, f.eks. fodgængernes angstprægede administration af blik og krop: 'y ust melt into the street and pretend your body doesn't exist. No musings; no sadness or happiness; no anything but the street, all empty inside, concentrating only on the next step you are about to take. «6 $\mathrm{Ti}$ år efter denne dystopiske version af det 20. århundredes storby, giver Auster med 
de to første filmprojekter, Smoke og Blue in the Face, en helt anderledes optimistisk versionering af $\mathrm{N}$ ew $\mathrm{Y}$ ork City.

\section{Filmenes Brooklyn. Levet sted}

Austers involvering i filmgenren har foreløbig udmøntet sig i Smoke og Blue in the Face begge fra 1995 samt Lulu on the B ridge ${ }^{17}$ fra 1998. Blue in the Face handler om hverdagslivet $\mathrm{i}$ et Brooklyn-kvarter med butikken The B rooklyn Cigar Company som midtpunkt. I deen til filmen opstod i kølvandet på optagelserne af Smoke, hvor A uggies cigarbutik er ramme om fem personers historie, som langsomt føjes sammen til spor i en fortælling om skrøbelige og forslåede, men også særdeles livsduelige mænd og kvinder. A uster og den kinesiske instruktør W ayne W angs idé var at genbruge butikken og en del af skuespillerne i en filmimprovisation over livet i Brooklyn. Manuskriptet til Blue in the Face udgøres derfor kun af ganskekorte tekster, en blanding af dialoger og beskrivelser af situationer som A uster har skrevet til skuespillerne. I optagelserne improviserer skuespillerne på baggrund af teksterne, og filmen der er optaget på kun seks dage, afviger væsentligt fra manuskriptet. ${ }^{18}$

Blue in the Face er inddelt i otte kapitler med overskrifter som »The B rooklyn Attitude« »T he Fortune Cookie«og »P atent P ending « der uden at kunne indordnes $i$ et plot fremstiller forskellige aspekter af livet i Brooklyn. I mellem enkelte personers (bl.a. Lou R eed og J im J armusch) foredrag af episoder, der har med bydelen og rygningen at gøre, præsenteres en rakke demografiske oplysninger om Brooklyn og klip fra fotografen Harvey Wangs videointerviews med mere ukendte lokale beboere. Et interview handler om et apparat til nedtagning af plasticposer, der er blæst op i træer, mens de statistiske oplysninger, der fremsiges af lokale på butikkens trappesten, omhandler antallet af religioner, kirker, etniske grupper, belgiske vafler, huller i vejene og mord i Brooklyn. Historisk dokumentarisk billedmateriale forekommer i sort/ hvid-klip med baseballspillere fra »T he Brooklyn Dodgers«, og de blandes igen med fiktive, improviserede scener spillet af Harvey K eitel, R oseanne og Madonna. Scenerne handler om den forsømte D ot, der drømmer om Las V egas, A uggies kærlighedsforhold og truslen om nedlukning af butikken. Kompositionen rammes ind af A uggies voice-over, der introducerer til de følgende kapitlers beskrivelse af en sommers begivenheder og afslutter med et 'det var hvad der skete'. Men filmen bryder rammen ved at lægge endnu et kapitel til med titlen »A year later « hvor snakken om baseball i A uggies cigarbutik fortsætter i de samme cirkler. Fraværet af samlende 
plot, additionen af fortællinger og sammenklipningen af billedmateriale med forskellig proveniens giver filmen et luftigt og flygtigt udtryk.

Smoke indledes med et billede af Manhattans skyline, en markant kontrast til det let forfaldne gadeudsnit omkring butikken i Brooklyn med lave bygninger og utidssvarende reklameskilte. B I ue in the F ace åbner med en zoomende bevægelse fra gengivelsen af et USA-kort, til kort over $\mathrm{N}$ ew $\mathrm{Y}$ ork, til kort over B rooklyn, til kortudsnit tilføjet cirkel og håndskrevet tekst: »Y ou are here« dvs. på hjørnet af 3rd Street og 7th A venue ved Prospect Park $\mathrm{i}$ B rooklyn. B evæel sen introducerer til filmens fokus på det absolut lokale og singulære. I Smoke indfanger Auggie stedets hverdagsliv i sine fotografier. $\mathrm{H}$ an fotograferer hjørnet hver morgen klokken otte og har 4000 billeder af det samme sted. Forfatteren Paul Benjamin, der køber sine cigarillos på hjørnet, forstår ikke monomanien i Auggies projekt, manglen på fortælling i billederne. A uggie forklarer, at man må dvæle ved billederne for at forstå dem. $V$ ed at følge billederne ser man lysets og årstidernes skift, man ser de faste aktører i gaden, og hvordan nye mennesker melder sig og langsomt bliver til kendte ansigter, mens velkendte forsvinder. Bl ue in the F ace forsøger i sin helhed at indfange og give en filmisk repræsentation af denne forbliven tilsat et minimum af forandring: hverdag på A uggies hjørne i Brooklyn.

Røgen og alle historierne som fortælles om rygningen (Raleighs introduktion af tobakken i England, Bakhtin der røg sit manuskript og film der lærer tilskuerne at ryge), er i filmene en protest mod det omgivende systems velmenende diktater og filmenes centrale metafor for livet og dets timelighed. Røgen er nydelse og kontemplation, men også en daglig øvelse i døden. Røgen sammenlignes i Smoke med sjælen. Den uhåndgribelige luftighed er fæleselementet mellem røg, sjæ og atmosfære. At forbyde røgen i et kollektivt rengøringsprojekt bliver dermed en parallel til den trussel kvarterets sjæ og særegenhed er udsat for, i Blue in the F ace konkretiseret med truslen om, at cigarbutikken må lukke til fordel for en helsekostforretning. Til den sammenkædning af røg, sjæl og atmosfære hører også tvivlen om, hvorvidt det overhovedet er muligt at indfange og fremstille hverdagslivets og kvarterets atmosfære. Genius loci er flygtig som menneskets tid, som røgens figurer og som kompositionens form.

Blue in the Face handler om hverdagslivet og dets tilknytning til et sted. Personerne indgår i sociale fællesskaber betinget af stedet. »H ow you look depends on where you go, «hedder det i sentensen fra lykkekagen i B lue in the $F$ ace. I dentiteten har altså sammenhæng med stedet og er formet af stedet; personerne hører til stedet. Med de Certeaus begreber fra L'invention du Quotidien fremmaner filmen et levet sted. ${ }^{19}$ D et består af menneskers praktikker, deres erindringer og fortællinger. Eksemplarisk tydeligt bliver det 
med omtalen af basebal lklubben »T he D odgers« Da klubben blev flyttet og deres stadion »E bbets F ield «jævnet med jorden, mistede B rooklyn en del af den bydelsidentitet, som hol det havde legemliggjort. De Certeau skriver om denne type fortæling: »D et er slående, at de steder, hvor folk bor, er som et nærvær af diverse fravær. $\mathrm{H}$ vad der kan ses, angiver det som ikke længere er der: 'Ser du, her plejede at være...' «(IQ, p.108). At et sted opfattes som beboeligt og hjemligt har ifølge de Certeau at gøre med disse usynlige identiteter i det synlige, dvs. erindringerne og fortæl lingerne der knytter sig til stedet. Blue in the Face forsøger med gengivel sen af sådanne fortælinger at skabe en visuel repræsentation af det levede sted. D et sker primært ved at lade kameraet køre foran personer, der leverer verbale fortæl linger om stedet og mindre ved at fortælle visuelt. Hvad der for betragteren skaber indtrykket af levet sted er i lige så høj grad de mange udfald mellem fortællingerne, hvor man præget af cirklerne og gentagelserne i samtalerne blot investerer flere gentagelser.

En optimisme på B rooklyn-borgernes vegne karakteriserer Blue in the Face. D et er en varm og mennesk ekærlig film. ${ }^{20}$ D en såkaldte Brooklyn-attitude grænser til det aggressive, og det ene skænderi afløser det andet, men konflikterne løses. Filmen er en hyldest til tolerancen og fællesskabet i B rooklyn og sål edes betragtet holder den sig ikke fri af en vis sentimentalitet og autenticitetsdyrkelse. Læst som et dokument, der også udtrykker en tids opfattelser af forskellige steder og rum, peger Blue in the F ace på en bevidsthed om tilstedeværelsen af humane kvaliteter i storbyens lokal samfund og deres sårbarhed i moderniteten. A usters eksplicitte hensigt med at sætte fokus på livet på hjørnet i B rooklyn er at aflive fordommene om, at N ew Y ork kun er et voldeligt, kriminelt shelvede på jorden «(SB, p.54). Og A usters modbillede hertil bliver altså en fremstilling af det levede steds flygtige væv af handlinger og fortællinger; et billede af et $\mathrm{N}$ ew $\mathrm{Y}$ ork-borough, der adskiller sig markant fra byrepræsentationerne i N ew Y ork-trilogien.

\section{Konklusioner}

I dentitetsproblematikken er omdrejningspunktet i Austers forfatterskab, og som vist er den i $\mathrm{N}$ ew $\mathrm{Y}$ ork-trilogien anskuet spatialt. J egets identitetsarbejde gives rumlige udtryk, f.eks. i metaforfeltet mellem gangen, skriften og læsningen, i gangens paradoksale kombination af selvforglemmelse og selvudforskning, i jegets isolerede ophold i hjemmets nøgne kulde eller i det aflåste værelse, men mødet med den anden, forelskelsen og den erotiske relation, vælger Auster også at indlejre i rummet i form af jegets aflæsning af husets 
inventar for erotiske erindringer. Samtidig er jegets bevægel ser fra rum til rum - fra lejligheden, ud i gaderne, ind i smøgen og op i nyt værelse - en litterær konkretisering af jegets indre rejse, hvor forskellige fortolkninger af selvet afløser hinanden i identitetseftersøgningen. I dentitetsproblematikkens spatiale udtryk suppleres i City of Glass af motivet om opdagelsesrejsende. Marco Polo og Columbus' optræden fungerer som markører af en heroisk (og til dels misforstået) livsrejse, mens referencerne til D on Quixotes tur på øget R osinante tilføjer bestræbel serne det komiske og ironiske skær, som eftersøgningen af identiteten også skal læses i. I dentitetsprojektet er altså konciperet som en rejse og en bevægelse; subjektet tænkes at bevæge og udvikle sig frem imod en mere færdigformet og gennemlyst identitet. Der er således i trilogien et dissonant spæendingsfelt mellem en teleologisk, essentialistisk identitetstænkning, der udmærket kan ses i forlængelse af det 19. århundredes udviklings- og dannelsesroman og så A usters underminering af denne opfattelse af identiteten med den legende, metafiktive eksplosion af jeget i teksten og kortets nonsens-udgave af en livsbane.

A usters film opbygger et univers, hvor identitetsproblematikken og specifikt forhol det mellem jeget og rummet er tænkt ganske anderledes. I filmene betragter A uster og Wang individet i dets sociale væren og denne værens knyttethed til stedet. Her forbliver personerne på det samme sted, en forbliven som filmen understreger med den cirkulære tid i årstiderne og i samtalens sig gentagende cirkler. D et jeg, som på én gang indædt eftersøges og legende aflyses i trilogien, er i filmene selvfølgeligt til stede og fremstilles i dets interaktion med andre. J eget er hjemmehørende i det sociale fællesskab. I billeder og tale repræsenterer B I ue in the F a ce således den sammenhæeng og historicitet $\mathrm{i}$ forholdet mellem sted og identitet som Michel de Certeau henviser til med begrebet levet sted og ikke mindst forestillingen om hverdagsfortælinger som spatial e fortæl linger, der skaber disse steder. I skarp kontrast til den betoning af subjektets knyttethed til sit sted står Quinns ukommenterede og ikke-erindringsfremkaldende blotte registrering af, at han passerer $\gg$ arick Street... where he had once lived «(N Y T , p. 107). Forestillingen om en identitetens stedsbundethed, en subjektets indfældning i et betydnings- og identitetsreflekterende bosted fremmanes og dementeres her i samme udsagn.

Trilogien og filmene giver litterære og visuelle repræsentationer af rum, der på hver deres måde dial ogiserer med sociologiske og kulturteoretiske diskurser om rummet og subjektets orientering og stilling i det. D et heterogene, diskontinuerte og paranoide rum i City of Glass er en litterær repræsentation af de orienteringsproblemer som F redric J ameson sammenfattede under begrebet hyperspace i 1980erne. I J amesons forståelse er hyperspace et rum, 
der spejler de perceptions-, reproduktions- og repræsentationsmæssige tilstande som multinationale netværksstrukturer og mediernes synkronicitet sæater for subjektet. ${ }^{21}$ J amesons protoeksempel på et hyperspace er J ohn Portmanns W estin B onaventure H otel i Los Angeles. Om hyperspace skriver han: »... this latest mutation in space - postmodern hyperspace - has finally succeeded in transcending the capacities off the individual human body to locate itself, to organize its immediate surroundings perceptually, and cognitively to map its position in a mappable external world«(PCLC, p.44) .

$V$ ed at skifte mellem repræsentationslogikker opbygger A uster et sådant hyperspace, den ideelle opbrudte rumlighed at lade jeget gennemrejse i eftersøgningen af en identitet. De mange gadenavne, den minutiøse rutebeskrivelse i romanen, gåture der bliver til bogstaver skrevet ind på kort, er i den forstand forsøg på at 'mappe' en subjektposition i en labyrintisk, objektiverende metropol, hvor gadenettet udgør et netværksniveau og tel efonnettet et uhåndgribeligt andet. ${ }^{22}$ Over for den rumkonception, som siden har fået sit udtryk par excellence i internettets multiplicerede rumkonstellationer, står det levede sted, som det forsøges indfanget i filmen Blue in the Face. Med be stræbelsen på at repræsentere en genius loci indskriver A uster og W ang sig i en modernitetsk ritisk tradition, der i mange forskellige variationer fokuserer på en beskrivelse og bevaring af de levede steder, de social e netværker knyttet til byens mange rum. Michel de Certeaus overvejel ser over fodgængernes bevægelse i byen, de singulære praktikker og fortælingers rumskabende funktion er hverdagssociologiens forsøg på begrebsligt at indfange den type rumlighed. I varierende udformninger ses samme interesse for det levede sted indenfor urbanstudierne tidligst hos J ane J acobs, senere i Marshall Berman og Richard Sennetts udgivelser og senest med antropologen Marc Augés kritiske analyse af ssupermodernitetens «ikke-steder (non-lieux), som vokser frem på bekostning af antropologiske rum. ${ }^{23}$

Filmenes indlejring af subjektet i et socialt rum, deres fokus på bykvarteret som levende organisme, er Austers bortmaning af den isolation, der frister og samtidig sætter trilogiens vandrende jeg på prøve. Gadehjørnets levede sted har afløst skakter og papæsker, og den hjemfarne, hjemmefødningen, A uggie bag disken, har afløst den evigt vandrende, udsultede flanør - kunne man sammenfatte. Men et udviklingsperspektiv af den art skygger for lighederne mellem filmene og romanernes versionering af jegets væren i rummet. I B rooklyn-filmenes levede sted angiver fortæallingerne om røgen hverdagslivets metafysiske dimension. I City of Glass danner de tel efonopringninger, der løber fejl, forestillingen om uendelige sammenhænge i netværket. N etværksbilledet som form konkretiserer en paranoid rumoplevelse, omgivelser som subjektet ikke kan kortlægge og positionere sig i, men samtidig også en 
transcendens på linie med den, der forbindes med ordet sit «i sæningen sit is raining « sthe state of is-ness that was the ground on which the happenings of the world took place « (NY T, p.111). Eller som det udtrykkes $\mathrm{i}$ The Invention of Solitude: »...the world is not just the sum of the things that are in it. It is the infinitely complex network of connections among them «(IS, p.161). I kke kun i det levede rums røgringe, men også i trilogiens sprængte, multiplicerede og heterogene rum indlægger A uster en transcendent dimension. I filmenes levede sted svarer det til hel heden af singulære livsudtryk, det luftige væv som er mere end summen af delene.

\section{Noter}

1. Der foreligger en omfattende litteratur om Austers trilogi, som jeg kortfattet vil opridse tendenserne i. I hovedtræk er der to grupper af læsninger: dels en dekonstruktiv og psykoanalytisk, dels en kulturteoretisk. Til den første hører: Bruce B awer: »D oubles and more doubles« in The N ew-Criterion, N ew Y ork 1989, der besk æftiger sig med fader/ søn-motivet. Fire dekonstruktivt inspirerede tilgange baseret på J acques Derrida findes hos A lison R ussell: »D econstructing The $\mathrm{N}$ ew Y ork Trilogy. Paul Auster's Anti-D etective Fiction « in Critique, vol.31, no.2 (1990), N orma Rowen: 》The D etective in Search of the Lost Tongue of A dam, «in Critique, vol.32, no.4 (1991), Bo K ampman W alter: » ortællinger efter faldet - om P aul Austers T he N ew Y ork T rilogy« in Synsvinkler, nr.11 (1995) og Steven E. Alford: »Mirrors of madness: Paul Auster's The N ew Y ork T rilogy « in Critique, vol.37, no.1 (1995). Sidste skud på stammen af dekonstruktivt inspirerede analyser er Bernd Herzogenraths A $n$ A rt of Desire, A msterdam \& Atlanta 1999, en Lacan/ Derrida-baseret læsning af udvalgte dele af A usters forfatterskab. Generelt arbejder disse analyser med at påvise romanens tematisering af différance i identitet og sprog. Et fælles problem i analyserne er, at romanen ikke udsættes for egentlig dekonstruktiv læsepraksis, men snarere betragtes som en eksemplifikation af dekonstruktiv sprogfilosofi. Samtidig lægger flere af analyserne (R ussell og K ampman Walter) detektiviske anstrengelser $i$ at efterspore romanens intertekstuelle væv af referencer, men overvejer ikke deres overordnede funktion som reflektorer af læserens potentielle fortolkningsmæssige overafkodning.

Til de kulturteoretiske hører Mireille R osello: »The Screener's Maps: Michel de Certeau's Wandersmänner and Paul Auster's Hypertextual Detective«, in H yper/ Text/ Theory, ed. George P. Landow, Baltimore 1994 og Steven E. Alford: "Spaced-Out: Signification and Space in Paul Auster's The N ew Y ork Trilogy in Contemporary Literature, vol.36, no.4 (1995). B egge artikler har som herværende Michel de Certeau som central reference. Hos R osello med en parallel mellem den gående og screeneren/ læserens navigering i hypertekstens rumlighed. H os A lford ligger fokus på forholdet mellem rum og selv. $\mathrm{H}$ an påpeger Quinns manglende forståelse af, at selvet er co-eksisterende med rummet. Til gruppen af kulturteoretisk funderet kritik vil jeg tillige regne F rederik Stjernfelt: $\gg$ wanna wake up in a city that never sleeps. P aul A usters N ew Y ork T rilogy: biografien som metafysisk problem《 in F redag 31 (1991), der med en viderebearbejdning af Greimas' 
narrative skema fokuserer på biografien som tema, men her indledes for så vidt også den topografisk orienterede vinkel, som jeg ligel edes tager op, med en bearbejdning af kortene i romanen. Peter K irkegaard: ' 'Cities, Signs, and Meaning in Walter Benjamin and Paul Auster, «in Orbis Litterarum, Vol.48, no.2/ 3 (1993 ) sammenholder Benjamins allegoriopfattelse med Austers tegn- og sprogovervejelser og anfører parallellen mellem Benjamins flanør-beskrivelse i Das P assagenW erk og A usters bybeskrivelse i trilogien. H vad angår identitetstematikken, når disse analyser (med en anden terminologi) for så vidt samme resultat som de førnæunte, men det sker gennem en mere induktivt orienteret tilgang, der samtidig tillader, at romanen kan diskuteres som værk og ikke reduceres til et tidsdokument fra postmodernismens glansperiode. Uden for den her valgte kategorisering ligger: Madeleine Sorapure: »T he Detective and the Author « in B eyond the R ed N otebook. Essays on Paul A uster, ed. Dennis Barone, Philadelphia 1995 og E rik Østerud: 》 skyggen av B abel. T ematik og intertekstualitet i Paul Austers The N ew Y ork Trilogy« in K \& K 77 (1994).

2. Paul Auster: The N ew Y ork Trilogy, London 1988, p. 3-4. Herefter forkortet NY T . T rilogiens tre romaner City of Glass, Ghosts og The L ocked R oom udkom i henholdsvis 1985, 1986 og 1987. På dansk N ew Y ork T rilogien, København 1993.

3. Michel de Certeau: L'invention du Quotidien. 1. A rts de faire, Paris 1990, p.155. Herefter forkortet I Q. Engelsk oversattelse: The P ractice of E veryday Life, Berkeley 1984.

4. Frederik Stjernfelt optegner også Quinns rute i artiklen » wanna wake up in a city that never sleeps« og når samme nonsens-resultat, men reflekterer ikke over læ serperspektivet.

5. Mireille R osello (jf. note 1) læser passagen som et eksempel på hypertekst, dvs. en ikke-sekventiel skrift, der er konstitueret af en serie tekststykker forbundet med links, som giver læseren valget mellem forskellige mulige stier. Michel de Certeaus vandrer opfatter R osello som den ideale bruger af en hyper-tekst. R osello betoner således også læserens rolle i forbindelse med kortene.

6. J f. A usters essay »T he art of Hunger «, der behandler sulteprocesser som et metaæstetisk fænomen primært hos Hamsun og K afka. Essayet er trykt i The A rt of H unger. E ssays. P refaces. Interviews, L os Angeles 1992. På dansk i K ritik 101 (1993). Sultlignende episoder ses ofte i A usters forfatterskab, f.eks. også i The Invention of Solitude og M oon Palace.

7. The Invention of Solitude, London, Boston 1982, p.100 og p.140. Herefter forkortet IS. P å dansk O pfindel sen af ensomhed, København 1990.

8. Marcel Proust: På sporet efter den tabte tid. V ejen til Swann, København 1963, p. 90-91. I The Invention of Solitude skriver Auster: 'M emory as a place, as a building, as a sequence of columns, cornices, porticoes. The body inside the mind, as if we were moving around in there, going from one place to the next, and the sound of our footsteps as we walk, moving from one place to the next«(IS, p.82).

9. E rik Østeruds artikel » skyggen av Babel. Tematik og intertekstualitet i P aul A usters The N ew Y ork T ril ogy«, giver med samme fokus $\mathrm{i}$ identitetens rumlige udtryk en mere omfattende analyse af The L ocked R oom.

10. Gaston Bachelard: La P oétique de l'espace, Paris 1974, p.18-19. Engelsk oversættelse: The P oetics of Space, Boston 1994. p.xxxvii.

11. Franco Moretti: A tlas of the E uropean N ovel 1800-1900, London/ N ew Y ork 1998 og J. Hillis Miller: Topographies, Stanford 1995 ligger til grund for den her an- 
vendte analysepraksis, hvor jeg bruger kort, og generelt for min kartografiske og topografiske tilgang til det litterære værk.

12. Biografiske oplysninger fra Paul A uster: Hand to mouth, London 1997, (N ew Y ork 1997), p.63 og http:/ / members.aol.com/ knkreutzer/ auster.

13. A uster skriver i The Invention of Solitude: »T he past, to repeat the words of P roust, is hidden in some material object. To wander about in the world, then, is also to wander about in ourselves. That is to say, the moment we step into the space of memory, we walk into the world «(IS, p. 166). Når Quinn går forbi V arick Street nr. 6, går Quinn rundt i Austers erindrede steder.

14. A uster blokerer demonstrativt erindringsbanerne i vandringen. $D$ en erindrende vandring kendes som motiv fra blandt andre W alter Benjamin, Franz H essel og Alfred K azins værker, hvor gensyn med steder under vandringen fører direkte ind i f.eks. barndomserindringer knyttet til stedet.

15. J eg refererer her til Frederik Tygstrups begreb om det systemiske percept fra artiklen: »D en litterære by« in K \& K 82 (1996). Også optrykt i F rederik Tygstrup: På sporet af virkeligheden, København 2000. Subjektets tilslutning til tel efonnettets abstraktestruktur modsvarer subjektets position i byens uanskuelige realitetsniveau.

16. Paul A uster: In the Country of Last Things, London 1990, p.57, (N ew Y ork 1987). På dansk I det sidstes I and, K øbenhavn 1990.

17. A usters roman The M usic of Chance er filmatiseret af Philip $\mathrm{H}$ aas, men uden A usters involvering i manuskriptet. På dansk Tilfæl dets musi k, K øbenhavn 1991.

18. Manuskriptet til Smoke, som både instruktøren W ayne Wang og Auster har bidraget til, bygger på A usters novelle «A uggie W ren's Christmas Story «trykt i N ew Y ork Times julen 1990. På dansk i Smoke \& Blue in the Face. To film af P aul A uster, København 1995. H erefter forkortet SB . A uster fungerer tillige som co-instruktør på Blue in the F ace.

19. Michel de Certeaus definition af rum (espace), som jeg sammenfatter med begrebet levet sted, lyder: ' R um [espace] optræder som en effekt produceret af de operationer, som orienterer det, situerer det, temporal iserer det og får det til at fungere i en poIyvalent enhed af konfliktuelle programmer eller kontraktuelle nærheder. Således betragtet, i relation til stedet [lieu], er rum ligesom ordet, når det tal es, dvs. når det gribes i aktualiseringens flertydighed... K ort fortalt, rum [espace] er et praktiseret sted [lieu] «(IQ, p.73).

20. A uster omtaler Smoke som det mest optimistiske, han har skrevet, jfr. SB, p.49.

21. F redric J ameson: » ostmodernism, or The Cultural Logic of Late Capitalism « in $\mathrm{N}$ ew L eft R evi ew, no.146, 1984. Senere optrykt i Fredric J ameson: P ostmodernism, or the cultural logic of late capitalism, London \& N ew Y ork 1991. Herefter forkortet PCLC.

22. H os A uster således at forsøget på at kortlægge omgivelserne komplementeres af fristelsen ved at lade sig fare vild og bevæge sig ind i ikke-stedet eller læsningens have.

23. Til forskel fra de Certeaus for estilling om læsningen og gangens utopiske ikke-sted, dvs. som et sted for subjektets modstandstaktikker, angiver Augés begreb non-lieu steder for transit, transport, konsum, fritids- og oplevelsesindustri, som anonymiserer og isolerer individet i et rum uden organisk socialt liv. I kke-stedets modsætning hos Marc A ugé er det antropologiske sted, som er ^formet af individuelle identiteter, gennem sprogets bidrag, lokale referencer, de uformulerede regler for hvordan man lever. «Marc Augé: N on-places. I ntroduction to an anthropology of supermodernity, London 1999, (p.101). Oversat af J ohn Howe fra N on-l ieux. Introduction à une anthropologie de la surmodernité, Paris 1992. 